\title{
A Cannabinoid $\mathrm{CB}_{\text {I }}$ Receptor-Positive Allosteric Modulator Reduces Neuropathic Pain in the Mouse with No Psychoactive Effects
}

\author{
Bogna M Ignatowska-Jankowska',,6, Gemma L Baillie ${ }^{2,6}$, Steven Kinsey ${ }^{3}$, Molly Crowe ${ }^{3}$, Sudeshna Ghosh', \\ Robert A Owens', Imad M Damaj', Justin Poklis', Jenny L Wiley ${ }^{4}$, Matteo Zanda ${ }^{5}$, Chiara Zanato ${ }^{5}$, \\ lain R Greig ${ }^{5}$, Aron H Lichtman ${ }^{1,7}$ and Ruth A Ross*,2,7 \\ 'Department of Pharmacology and Toxicology, Virginia Commonwealth University, Richmond, VA, USA; ${ }^{2}$ Department of Pharmacology and \\ Toxicology, University of Toronto and Campbell Family Mental Health Research Institute, Centre for Addiction and Mental Health, Toronto, Ontario, \\ Canada; ${ }^{3}$ Department of Psychology, West Virginia University, Morgantown, WV, USA; ${ }^{4}$ Research Triangle Institute, Research Triangle Park, NC, \\ USA; ${ }^{5}$ School of Medical Sciences, Institute of Medical Sciences, University of Aberdeen, Aberdeen, UK
}

The $C_{1}$, receptor represents a promising target for the treatment of several disorders including pain-related disease states. However, therapeutic applications of $\Delta^{9}$-tetrahydrocannabinol and other $C_{1}$ orthosteric receptor agonists remain limited because of psychoactive side effects. Positive allosteric modulators (PAMs) offer an alternative approach to enhance $C_{B}$, receptor function for therapeutic gain with the promise of reduced side effects. Here we describe the development of the novel synthetic CB, PAM, 6-methyl-3-(2-nitro- I-(thiophen2-yl)ethyl)-2-phenyl- I H-indole (ZCZOII), which augments the in vitro and in vivo pharmacological actions of the CB, orthosteric agonists CP55,940 and $\mathrm{N}$-arachidonoylethanolamine (AEA). ZCZOII potentiated binding of $\left[{ }^{3} \mathrm{H}\right] \mathrm{CP} 55,940$ to the $\mathrm{CB}_{\text {। }}$ receptor as well as enhancing AEA-stimulated $\left[{ }^{35} \mathrm{~S}\right] \mathrm{GTP} \gamma \mathrm{S}$ binding in mouse brain membranes and $\beta$-arrestin recruitment and ERK phosphorylation in hCB, cells. In the whole animal, ZCZOII is brain penetrant, increased the potency of these orthosteric agonists in mouse behavioral assays indicative of cannabimimetic activity, including antinociception, hypothermia, catalepsy, locomotor activity, and in the drug discrimination paradigm. Administration of ZCZOII alone was devoid of activity in these assays and did not produce a conditioned place preference or aversion, but elicited $C B_{1}$ receptor-mediated antinociceptive effects in the chronic constriction nerve injury model of neuropathic pain and carrageenan model of inflammatory pain. These data suggest that ZCZOI I acts as a CB, PAM and provide the first proof of principle that CB, PAMs offer a promising strategy to treat neuropathic and inflammatory pain with minimal or no cannabimimetic side effects. Neuropsychopharmacology (20I5) 40, 2948-2959; doi: I0.1038/npp.20I5.I48; published online 29 July 2015

\section{INTRODUCTION}

Endocannabinoids ( $\mathrm{N}$-arachidonoylethanolamine (anandamide, AEA) and 2-arachidoloylglycerol (2-AG)) are released on demand in response to various stimuli, including pain. Through their stimulation of $\mathrm{CB}_{1}$ receptors, they inhibit pain transmission at central, spinal, and peripheral synapses and may serve an auto-protective role (Walker et al, 1999). Although preclinical data indicate that $\Delta^{9}$-tetrahydrocannabinol (THC), the primary psychoactive constituent of Cannabis (Gaoni and Mechoulam, 1964), and other direct $\mathrm{CB}_{1}$ receptor agonists are also effective antinociceptive

*Correspondence: Dr R Ross, Department of Pharmacology and Toxicology, University of Toronto and Campbell Family Mental Health Research Institute, Centre for Addiction and Mental Health, Toronto, Ontario, M5S IA8 Canada, Tel: +4I6946 7959, Fax: +4I6978 6395,

E-mail: ruth.ross@utoronto.ca

6oint first authors.

7 Joint corresponding authors

Received 13 January 2015; revised 19 May 2015; accepted 20 May 2015; accepted article preview online 8 June 2015; agents in laboratory animal models of neurodegenerative, neuroinflammatory, and pain-related disease states (Guindon and Hohmann, 2009; Pryce and Baker, 2012; Fagan and Campbell, 2014), their distinct cannabimimetic side-effect profile, which includes abuse, dependence, and memory impairment (Lichtman et al, 1995; Hutcheson et al, 1998; Hampson and Deadwyler, 2000; Justinova et al, 2003; Cooper and Haney, 2009), limits therapeutic use and further development. Direct agonists, including THC, target the orthosteric binding pocket on the $\mathrm{CB}_{1}$ receptor and initiate global activation of the receptor, which is heterogeneously expressed in brain, spinal cord, and periphery. Although endocannabinoids also bind orthosterically (Devane et al, 1992; Mechoulam et al, 1995; Sugiura et al, 1995), they are released on demand where needed and are quickly metabolized (Di Marzo et al, 1999); hence, their actions are more transient and selective with highly specific temporal and spatial regulation. Allosteric modulators may offer a similarly selective approach for alteration of $\mathrm{CB}_{1}$ receptor signaling, presumably with reduced pharmacodynamic-related 
side effects. Allosteric modulators bind to a distinct, non-orthosteric site on the receptor, and elicit conformational changes that alter ligand potency and/or efficacy (Kenakin, 2004,2013). Accordingly, it has been hypothesized that $\mathrm{CB}_{1}$-positive allosteric modulators (PAMs) should enhance antinociceptive and other functional effects of endogenously released cannabinoids, but with limited cannabimimetic side effects (Pertwee, 2005; Ross, 2007a,b).

Initially reported $\mathrm{CB}_{1}$ receptor allosteric modulators were based on a series of Organon compounds, which enhanced orthosteric binding in a ligand-dependent manner, but paradoxically, inhibited signal transduction (Price et al, 2005). These, and other allosteric modulators of the $\mathrm{CB}_{1}$ receptor, have been characterized on the basis of their actions in radioligand-binding assays and other functional in vitro assays of $\mathrm{CB}_{1}$ receptor signal transduction (Horswill et al, 2007; Navarro et al, 2009; Pamplona et al, 2012; Piscitelli et al, 2012; Ahn et al, 2013; Baillie et al, 2013). In vivo, the purported negative allosteric modulator, PSNCBAM-1, reduced food intake (Horswill et al, 2007), an action consistent with $\mathrm{CB}_{1}$ orthosteric antagonism (Di Marzo et al, 2001), although $\mathrm{CB}_{1}$ receptor mediation of this anorectic effect was not ascertained. Another purported $\mathrm{CB}_{1}$-negative allosteric modulator, ORG27569, reduced food intake, but this effect was $\mathrm{CB}_{1}$ receptor independent (Gamage et al, 2014). Moreover, this compound generally failed to modify the pharmacological effects of $\mathrm{CB}_{1}$ orthosteric agonists in common rodent models indicative of $\mathrm{CB}_{1}$ receptor activity (Gamage et al, 2014). Likewise, ORG27569 generally did not perform as a CB1 receptor allosteric modulator in rats (Ding et al, 2014). Although it attenuated both cue- and drug-induced reinstatement of cocaine and methamphetamine-seeking behavior in rats, $\mathrm{CB}_{1}$ receptor involvement was not determined (Jing et al, 2014). The first compelling pharmacological evidence demonstrating the effectiveness of a $\mathrm{CB}_{1}$ receptor allosteric modulator in whole animals came from Pamplona et al (2012). They found that the endogenous anti-inflammatory mediator, lipoxin A4, enhanced the pharmacological effects of AEA at the $\mathrm{CB}_{1}$ receptor both in vitro and in vivo, as well as protected against $\beta$-amyloid (1-40)-induced performance deficits in the Morris water maze in mice (Pamplona et al, 2012).

In the present study, we examined a novel small-molecule $\mathrm{CB}_{1}$ PAM, ZCZ011 (Figure 1a), in in vitro and in vivo assays to evaluate whether it behaves as a CB1 PAM. In vitro, ZCZ011 increased the $\mathrm{CB}_{1}$ receptor agonist receptor binding and potentiated AEA-stimulated signaling in $\left[{ }^{35} \mathrm{~S}\right] \mathrm{GTP} \gamma \mathrm{S}$ binding, $\beta$-arrestin recruitment, and ERK phosphorylation assays. As there remains a tremendous need for new medications to treat chronic pain conditions (Nightingale, 2012), we tested whether this compound would reduce nociceptive behavior in the chronic constriction injury (CCI) model of neuropathic pain, as well as in the carrageenan model of inflammatory pain. Each of these assays is highly sensitive to the antinociceptive effects of orthosteric $\mathrm{CB}_{1}$ agonists and inhibitors of endocannabinoid catabolic enzymes (Lichtman et al, 2004; Russo et al, 2007; Kinsey et al, 2009; Ghosh et al, 2013). In addition, we examined ZCZ011 by itself or in combination with orthosteric $\mathrm{CB}_{1}$ receptor agonists in a range of common assays sensitive to cannabimimetic activity, including the tetrad tests (locomotor activity, antinociception, catalepsy, and hypothermia; (Little et $a l, 1988)$ ) and drug discrimination (Jarbe et al,
1981). Finally, we tested whether systemically administered ZCZ011 was brain penetrant and whether it altered endocannabinoid levels in the brain. Here, we demonstrate the first evidence of a $\mathrm{CB}_{1}$ PAM that exhibits antinociceptive effects in neuropathic and inflammatory pain models with no associated cannabimimetic effects.

\section{MATERIALS AND METHODS}

\section{Animals}

Male C57BL/6 J mice (Jackson Laboratory, Bar Harbor, ME) and male FAAH (-/ - ) mice, backcrossed onto a C57BL/6 J background for at least 13 generations served as subjects. FAAH $(-/-)$ mice were employed in all experiments examining the in vivo actions of exogenously administered AEA to prevent its rapid hydrolysis to arachidonic acid, which is known to produce CB1 receptor-independent effects (Wiley et al., 2006). Although constitutively elevated levels of AEA and other lipids in FAAH $(-/-)$ mice might complicate interpretation, it should be noted that these mice display normal CB1 receptor expression and function (Cravatt et al., 2001; Lichtman et al., 2002; Falenski et al., 2010). All animal protocols were approved by the respective Institutional Animal Care and Use Committees at Virginia Commonwealth University and West Virginia University and were in accordance with the National Institutes of Health Guide for the Care and Use of Laboratory Animals (National Research Council, 2011).Other details are included in the Supplementary Information.

\section{Materials}

ZCZ011 (6-Methyl-3-(2-nitro-1-(thiophen-2-yl)ethyl)-2-phenyl- $1 \mathrm{H}$-indole) was synthesized at the University of Aberdeen (see synthesis below). AEA was provided by Organix Inc. (Woburn, MA). The pan $\mathrm{CB}_{1} / \mathrm{CB}_{2}$ receptor agonist CP55,940, the $\mathrm{CB}_{1}$ receptor antagonist rimonabant ( $N$-(piperidin-1-yl)5-(4-chlorophenyl)-1-(2,4-dichlorophenyl)-4-methyl-1H-pyrazole-3-carboxamide-HCl; SR141716A), and the $\mathrm{CB}_{2}$ receptor antagonist SR144528 (5-(4-chloro-3-methylphenyl)-1-((4methylphenyl)methyl)-N-((1,2S,4R)-1,3,3-trimethylbicyclo [2.2.1] hept-2-yl]-1H-pyrazole-3-carboxamide) were obtained from the National Institute on Drug Abuse Drug Supply Program (Bethesda, MD). Drugs were dissolved in a vehicle consisting of a mixture of ethanol, alkamuls-620 (SanofiAventis, Bridgewater, $\mathrm{NJ})$, and saline $(0.9 \% \mathrm{NaCl})$ in a ratio of $1: 1: 18$. Each drug was given via the intraperitoneal (i.p.) route of administration with exception of the discrimination studies, in which drugs were injected via subcutaneous (s.c.) route of administration. All drugs were administered at a volume of $10 \mu \mathrm{l} / \mathrm{g}$ body mass.

\section{Synthesis of ZCZ011}

See Supplementary Information for complete details.

\section{Mouse Brain Membrane Preparation}

Whole brains from adult male MF1 mice were suspended in centrifugation buffer ( $320 \mathrm{mM}$ sucrose, $2 \mathrm{mM}$ EDTA, $5 \mathrm{mM}$ $\mathrm{MgCl}_{2}$ ) and the tissues were homogenized with an Ultra- 
a<smiles>[R]OC(=O)O</smiles>

b

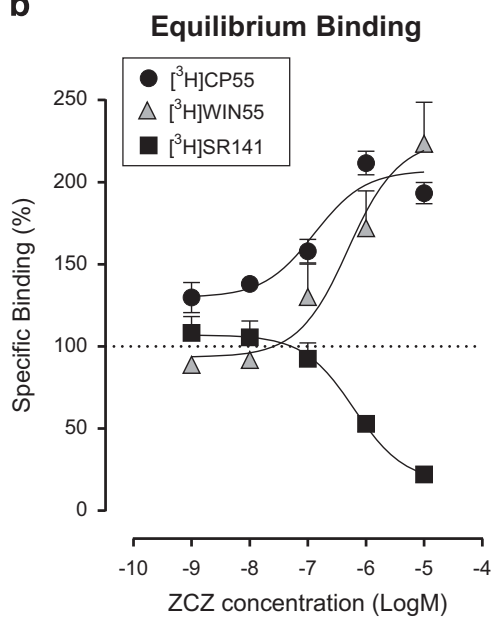

C

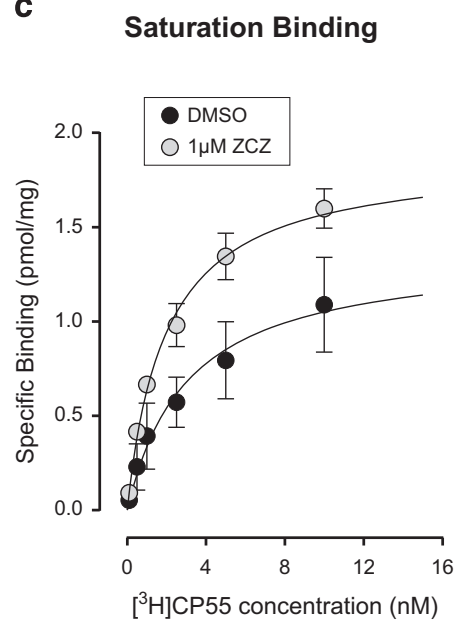

d

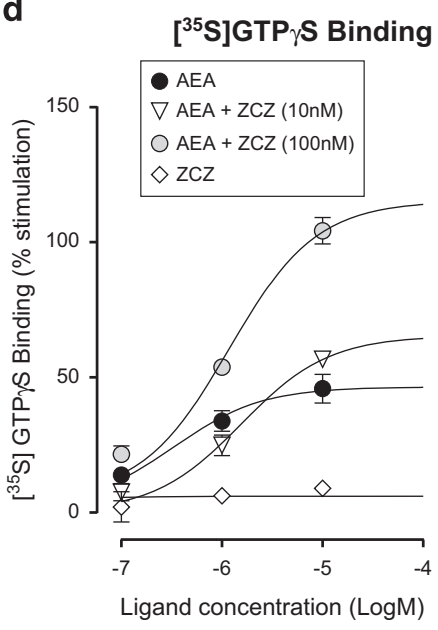

e

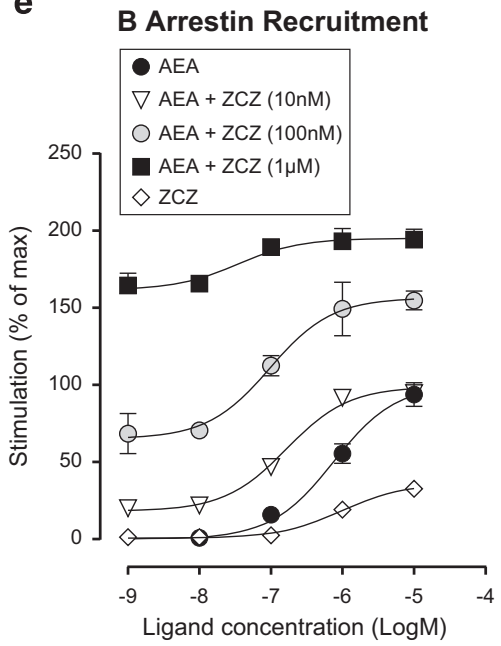

f

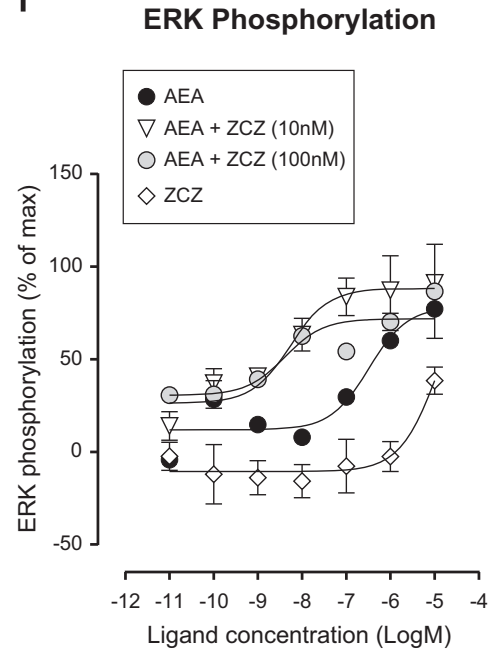

g cAMP Production

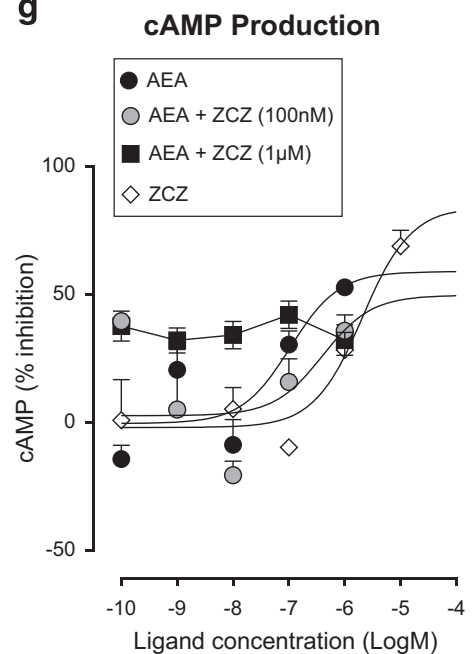

Figure I The $C B_{1}$-positive allosteric modulator ZCZO I I enhances $C B_{1}$ receptor binding and signaling. (a) Chemical structure of ZCZOI I. (b) ZCZO I I significantly increased $\left[{ }^{3} \mathrm{H}\right] \mathrm{CP} 55,940$ binding in mouse brain membranes. (c) ZCZOII caused a significant increase in the $B_{\max }$ for $\left[{ }^{3} \mathrm{H}\right] \mathrm{CP} 55,940$ and $\left[{ }^{3} \mathrm{H}\right]$ WIN552 I 2 while having no effect on the $K_{d}$. ZCZOII caused an apparent displacement of $\left.{ }^{3} \mathrm{H}\right] \mathrm{SR}$ I 4 I I I 6A. (d) ZCZOII caused a significant increase in the efficacy of AEA-stimulated $\left[{ }^{35} \mathrm{~S}\right] \mathrm{GTP} \gamma \mathrm{S}$ binding in mouse brain membranes. (e) ZCZO I caused a significant increase in AEA-stimulated $\beta$-arrestin recruitment in $h C B_{1}$ cells. ( $f$ ) ZCZOI I caused a significant increase in the potency of AEA to stimulate ERK I/2 phosphorylation in hCB 1 -expressing cells. (g) Effect of

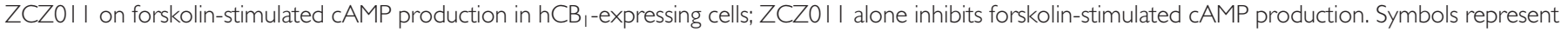
mean values \pm SEM from 2 to 7 independent experiments.

Turrex homogenizer (see Supplementary Information). Tissue homogenates were centrifuged at $1600 \mathrm{~g}$ for $10 \mathrm{~min}$ and the resulting supernatant collected. This pellet was resuspended in centrifugation buffer centrifuged as before and the supernatant collected. Supernatants were combined before undergoing further centrifugation at $28000 \mathrm{~g}$ for $20 \mathrm{~min}$. The supernatant was discarded and the pellet resuspended in buffer A (50 mM Tris, $2 \mathrm{mM}$ EDTA, $5 \mathrm{mM} \mathrm{MgCl}_{2}$ at $\mathrm{pH} 7.0$ ) and incubated at $37^{\circ} \mathrm{C}$ for $10 \mathrm{~min}$. Following the incubation, the suspension was centrifuged for $20 \mathrm{~min}$ at $23000 \mathrm{~g}$. After resuspending the pellet in buffer $\mathrm{A}$, the suspension was incubated for $40 \mathrm{~min}$ at room temperature before a final centrifugation for $15 \mathrm{~min}$ at $11000 \mathrm{~g}$. The final pellet was resuspended in buffer $B(50 \mathrm{mM}$ Tris, $1 \mathrm{mM}$ EDTA, $3 \mathrm{mM}$ $\mathrm{MgCl}_{2}$ ) and the final protein concentration, determined by Bio-Rad Dc kit, was $1 \mathrm{mg} / \mathrm{ml}$. All centrifugation procedures were carried out at $4{ }^{\circ} \mathrm{C}$. Prepared brain membranes were stored at $-80^{\circ} \mathrm{C}$ and defrosted on the day of the experiment.

\section{CHO-hCB1R Cells}

$\mathrm{CHO}$ cells stably transfected with cDNA encoding human cannabinoid $\mathrm{CB}_{1}$ receptors (see Baillie et al., 2013) were maintained in Dulbecco's modified Eagles's medium (DMEM) nutrient mixture F-12 HAM, supplemented with $2 \mathrm{mM} \mathrm{L}$ glutamine, $10 \%$ fetal bovine serum, $0.6 \%$ penicillin-streptomycin, hygromycin B $(300 \mu \mathrm{g} / \mathrm{ml})$ and geneticin $(600 \mu \mathrm{g} / \mathrm{ml})$. All cells were maintained at $37^{\circ} \mathrm{C}$ and $5 \% \mathrm{CO}_{2}$ in their respective media and were passaged twice a week using nonenzymatic cell dissociation solution. The $\mathrm{CHO}^{-} \mathrm{hCB}{ }_{1} \mathrm{R}-$ transfected cell line was used for cAMP and pERK1/2.

\section{Equilibrium Binding Assays}

Equilibrium binding assays were carried out using $\left[{ }^{3} \mathrm{H}\right]$ CP55,940, $\left[{ }^{3} \mathrm{H}\right]$ WIN55212, and $\left[{ }^{3} \mathrm{H}\right] \mathrm{SR} 141716 \mathrm{~A}$ concentrations of $0.7,1.2$ and $1 \mathrm{nM}$, respectively. BSA $(1 \mathrm{mg} / \mathrm{ml})$ and 
$50 \mathrm{mM}$ Tris buffer was used in a total assay volume of $500 \mu \mathrm{l}$ containing $0.01 \%$ DMSO. Binding was initiated by adding $30 \mu \mathrm{g}$ of mouse brain membranes, as previously described (Baillie et al, 2013). Assays were incubated at $37^{\circ} \mathrm{C}$ for $60 \mathrm{~min}$, and then the reaction was stopped by the addition of ice-cold wash buffer that contained $50 \mathrm{mM}$ Tris buffer and $1 \mathrm{mg} / \mathrm{ml} \mathrm{BSA}$ and vacuum filtration using a 24-well sampling manifold Brandel cell harvester (Gaithersburg, MD). Specific binding is defined as the difference between the binding that occurred in the presence and absence of $1 \mu \mathrm{M}$ unlabeled ligand and varied between 70 and $90 \%$ of the total binding.

\section{$\left[{ }^{35}\right.$ S $]$ GTP $\gamma$ S-Binding Assay}

Mouse brain membranes $(5 \mu \mathrm{g}$ protein) were preincubated for $30 \mathrm{~min}$ at $30^{\circ} \mathrm{C}$ with adenosine deaminase $(0.5 \mathrm{U} / \mathrm{ml})$. The membranes were then incubated with the agonist \pm modulator or vehicle for $60 \mathrm{~min}$ at $30^{\circ} \mathrm{C}$ in assay buffer

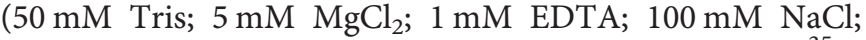
$1 \mathrm{mM}$ DTT; $0.1 \% \mathrm{BSA})$ in the presence of $0.1 \mathrm{nM}\left[{ }^{35} \mathrm{~S}\right]$ GTP $\gamma$ S and $30 \mu \mathrm{M}$ GDP. Binding was initiated by the addition of $\left[{ }^{35} \mathrm{~S}\right] \mathrm{GTP} \gamma \mathrm{S}$. Nonspecific binding was measured in the presence of $30 \mu \mathrm{M}$ GTP $\gamma \mathrm{S}$. The reaction was terminated by rapid vacuum filtration $(50 \mathrm{mM}$ Tris- $\mathrm{HCl}$; $50 \mathrm{mM}$ Tris-Base; $0.1 \%$ BSA) using a 24-well sampling manifold (cell harvester; Brandel, Gaitherburg, MD) and GF/ B filters (Whatman, Maidstone, UK).

Data analysis. Raw data were presented as cpm. Basal level was defined as zero. Results were calculated as a percentage change from basal level of $\left[{ }^{35} \mathrm{~S}\right] \mathrm{GTP} \gamma \mathrm{S}$ binding (in the presence of vehicle). Data were analyzed by nonlinear regression analysis of sigmoidal dose response curves using GraphPad Prism 5.0 (GraphPad, San Diego, CA). The results of this analysis are presented as $E_{\max }$ with $95 \%$ confidence limits (CLs) and $\mathrm{pEC}_{50}(\log \mathrm{EC} 50) \pm$ SEM.

\section{PathHunter $\mathrm{CB}_{1} \beta$-Arrestin Assays}

PathHunter hCB $\beta$-arrestin cells were plated $48 \mathrm{~h}$ before use and incubated at $37^{\circ} \mathrm{C}, 5 \% \mathrm{CO}_{2}$. Compounds were dissolved in DMSO and diluted in OCC media. Five microliters of allosteric modulator or vehicle solution were added to each well and incubated for $60 \mathrm{~min}$. Five microliters of agonist were added to each well followed by a 90 -min incubation. Fifty-five microliters of detection reagent are then added followed by further $90 \mathrm{~min}$ incubation at room temperature. Chemiluminescence, indicated as relative light unit, was measured on a standard luminescence plate reader.

Data analysis. Raw data were relative light units. Basal level was defined as zero. Results were calculated as the percentage of CP55940 maximum effect. Data were analyzed by nonlinear regression analysis of sigmoidal dose-response curves using GraphPad Prism 5.0. The results of this analysis are presented as $E_{\max }$ with $95 \% \mathrm{CLs}$ and $\mathrm{pEC}_{50}\left(\operatorname{logEC_{50}}\right) \pm$ SEM.

\section{AlphaScreen SureFire ERK 1/2 phosphorylation assay}

ERK1/2 MAP-kinase phosphorylation assay. For experimental studies of ERK1/2 MAP-kinase phosphorylation, $\mathrm{hCB}_{1} \mathrm{R}$ cells (40 000 cells/well) were plated onto 96-well plates and serum-starved for $24 \mathrm{~h}$. Cells were then washed with DMEM before the addition of agonist \pm Org 27569 or vehicle at the desired concentration. After a 6 -min incubation at $37^{\circ} \mathrm{C}$ in a humidified atmosphere, ice-cold lysis buffer (provided with the AlphaScreen SureFire kit) was added to each well and the plate was placed at $-80^{\circ} \mathrm{C}$ for at least $1 \mathrm{~h}$.

AlphaScreen SureFire ERK assay. The assay was performed in 384-well white Proxiplates according to the manufacturer's instructions. Briefly, $4 \mu \mathrm{l}$ samples were incubated with $7 \mu \mathrm{l}$ of mixture containing $=1$ part donor beads: 1 part acceptor beads: 10 parts activation buffer: 60 parts reaction buffer. Plates were incubated for $3 \mathrm{~h}$ at $25^{\circ} \mathrm{C}$ in the dark and read with the Envision system (PerkinElmer) using AlphaScreen settings.

Data analysis. Raw data were presented as 'Envision units'. Basal level was defined as zero. Results were presented as means and variability as SEM or $95 \%$ CLs of the percent stimulation of phosphorylated ERK1/2 above the basal level (in the presence of vehicle). Data were analyzed by nonlinear analysis of log agonist $v s$ response curves using GraphPad Prism 5.0. The results of this analysis were presented as $E_{\max }$ with $95 \%$ CLs and $\mathrm{pEC}_{50}\left(\operatorname{logEC_{50}}\right) \pm$ SEM.

\section{DiscoverX cAMP Assays}

For experimental studies of inhibition of cAMP formation, hCB1R cells (20 000 cells/well) were plated into 96-well plates and serum starved for $24 \mathrm{~h}$. Cells were then washed with serum- and phenol-free DMEM before the addition of agonist with vehicle/allosteric modulator in the presence of $10 \mu \mathrm{M}$ rolipram and $10 \mu \mathrm{M}$ forskolin. Cells were stimulated for $30 \mathrm{~min}$ at $37^{\circ} \mathrm{C}$ in a humidified atmosphere. The DiscoverX cAMP kit was then used and a standard curve was included in every assay. Antibody solution was added to each well followed by working solution: 1 part ED solution and 1 part combination of lysis (19), Emerald solution (5) and Gal (1). Plates were incubated at room temperature for $60 \mathrm{~min}$. A final addition of EA reagent to each well was followed by incubation at room temperature for no less than 3 but no more than $18 \mathrm{~h}$ and plates were read using a luminescence plate reader.

Data analysis. Results were calculated as the percentage inhibition of forskolin-stimulated cAMP production. Data were analyzed by nonlinear regression analysis of sigmoidal dose-response curves using GraphPad Prism 5.0. The results of this analysis were presented as $E_{\max }$ with $95 \%$ CLs and $\mathrm{pEC}_{50}\left(\log \mathrm{EC}_{50}\right) \pm \mathrm{SEM}$.

\section{Model of Neuropathic Pain}

CCI nerve injury was induced according to the surgical procedures described previously (Kinsey et al, 2009), as detailed in Supplementary Methods. ZCZ011 (0, 10, 20, $40 \mathrm{mg} / \mathrm{kg}$ ) was injected via the i.p. route of administration and mice were tested for mechanical and cold allodynia 75 min later. ZCZ011 was administered in a counterbalanced Latin square within subject design with at least a 5-day wash 
out period between tests. To assess the effects of repeated treatment of ZCZ011 (40 mg/kg, i.p.) on mechanical and cold allodynia induced by CCI, mice were divided into the following three experimental groups: (1) vehicle control (6 days of vehicle injections); (2) acute ZCZ011 (5 days of vehicle injections and injected with $40 \mathrm{mg} / \mathrm{kg}$ ZCZ011 on day 6); and (3) repeated ZCZ011 (6 days of injections of $40 \mathrm{mg} / \mathrm{kg}$ ZCZ011). In the repeated ZCZ011 group, mechanical and cold allodynia were assessed 1, 2, 4, 12, and $24 \mathrm{~h}$ following the first ZCZ011 injection to determine duration of acute anti-allodynic effects of ZCZ011. The subjects in all groups were tested $1 \mathrm{~h}$ following ZCZ011 administration on day 6. In experiments assessing cannabinoid receptor mechanism of action, rimonabant $(3 \mathrm{mg} / \mathrm{kg}$ ) or SR144528 $(3 \mathrm{mg} / \mathrm{kg})$ was administered $10 \mathrm{~min}$ before ZCZ011 or vehicle. Mechanical allodynia was assessed using von Frey filaments and the acetone flinching test was used to assess cold allodynia, as described previously (Kinsey et al, 2009) and detailed in Supplementary Information.

\section{Carrageenan Model of Inflammatory Pain}

Edema was induced via intraplantar injection of $0.3 \%$ carrageenan (Sigma, St Louis, MO) in a $20 \mu \mathrm{l}$ volume using a 30-G needle into the hind left paw. Paw thickness was measured with an electronic digital micrometer (Traceable Calipers, Friendswood, TX) before and $5 \mathrm{~h}$ following carrageenan administration, which corresponds to peak edema (Wise et al, 2008). Paw edema data are expressed as the difference in paw thickness between the $5 \mathrm{~h}$ and preinjection measures. Mechanical allodynia was assessed using von Frey filaments at the same peak time point (see Supplementary Information).

\section{Tetrad Assay}

The behavioral testing was conducted in the following order: bar test (catalepsy), tail withdrawal test, and rectal temperature. A separate group of mice was used to assess the effects of ZCZ011 on locomotor activity. Testing was performed according to the previously described procedures (Long et al, 2009b; Schlosburg et al, 2010). For a full description, see Supplementary Information.

\section{Drug Discrimination}

Male C57BL/6J and FAAH (- / - ) mice (20-25 g) trained to discriminate CP55,940 $(0.1 \mathrm{mg} / \mathrm{kg})$ or AEA $(6 \mathrm{mg} / \mathrm{kg})$ from vehicle, respectively, were tested in a nose-poke operant task according to the procedures described previously (Long et al, $2009 b$ ) with minor modifications. For complete description of these procedures, see Supplementary Information.

\section{ZCZ011 Place Conditioning}

An unbiased mouse CPP paradigm was utilized, as previously described (Kota et al, 2008), in which vehicle, ZCZ011 (40 mg/kg), or cocaine (10 mg/kg; positive control) was randomly paired with one of two distinct chambers. On the test day, mice did not receive an injection and were allowed to roam freely for $15 \mathrm{~min}$ while the percentage of time spent in both chambers was scored as the dependent measure. For further details, see Supplementary Information.

\section{Extraction and Quantification of Endocannabinoids by Liquid Chromatography-Tandem Mass Spectrometry}

C57BL/6J mice were administered ZCZ011 (40 mg/kg) acutely and killed 45 min later (see Supplementary Information). Brains were harvested and the concentrations of 2-AG, AEA, palmitoylethanolamide, oleoylethanolamide, and arachidonic acid levels were quantified, as previously described (Ignatowska-Jankowska et al, 2014) and detailed in Supplementary Information.

\section{Data Analyses}

All in vivo data are presented as mean \pm standard error (SEM) or 95\% CLs. In vitro data were analyzed using log agonist $v s$ response curves in GraphPad Prism 5.0. The results of this analysis were presented as $E_{\max }$ with $95 \%$ CLs and $\mathrm{pEC}_{50}\left(\log \mathrm{EC}_{50}\right) \pm \mathrm{SEM}$. In vivo data were analyzed using one-way or two-way analysis of variance (ANOVA). Dunnett's test was used for post hoc analysis in the doseresponse experiments, and the Tukey test was used for post hoc analyses comparing different treatment groups. Multiple comparisons following two-way ANOVA were conducted with Bonferroni post hoc comparisons. Differences were considered significant at the level of $P<0.05$. Statistical analysis was performed with GraphPad Prism version 5.00.

\section{RESULTS}

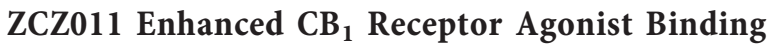

In equilibrium binding experiments, ZCZ011 (Figure 1a) produced a significant and concentration-dependent increase in the specific binding of the $\mathrm{CB}_{1}$ receptor orthosteric agonist $\left[{ }^{3} \mathrm{H}\right] \mathrm{CP} 55,940$ to mouse brain membranes with an $E_{\max }$ of $207 \%$ (95\% CLs, 191-223) and a $\mathrm{pEC}_{50}$ of $6.90 \pm 0.23$ (Figure 1b). ZCZ011 also produced a significant and concentration-dependent increase in the specific binding of the $\mathrm{CB}_{1}$ receptor orthosteric agonist $\left[{ }^{3} \mathrm{H}\right]$ WIN55212 to mouse brain membranes with an $E_{\max }$ of $225 \%$ (95\% CLs, $182-269$ ) and a $\mathrm{pEC}_{50}$ of $6.31 \pm 0.33$ (Figure $1 \mathrm{~b}$ ). In contrast, ZCZ011 produced a significant and concentrationdependent decrease in the specific binding of the $\mathrm{CB}_{1}$ receptor orthosteric inverse agonist $\left[{ }^{3} \mathrm{H}\right] \mathrm{SR} 141716 \mathrm{~A}$ to mouse brain membranes with an $E_{\max }$ of $17 \%$ (95\% CLs, -2.7 to 37 ) and a $\mathrm{pEC}_{50}$ of $6.21 \pm 0.21$ (Figure $1 \mathrm{~b}$ ).

In saturation binding experiments, $\left[{ }^{3} \mathrm{H}\right] \mathrm{CP} 55,940$ bound in a saturable manner to the $\mathrm{CB}_{1}$ receptor with a $B_{\max }$ of $1.37 \mathrm{pmol} / \mathrm{mg}$ (95\% CLs, $1.042-1.704)$ and $K_{\mathrm{d}}$ of $3.10 \pm$ $0.9 \mathrm{nM}$ (Figure 1c). ZCZ011 (1 $\mu \mathrm{M})$ significantly increased the $B_{\max }$ value of $\left[{ }^{3} \mathrm{H}\right] \mathrm{CP} 55,940$ to $1.88 \mathrm{pmol} / \mathrm{mg}$ (95\% CLs, 1.728-2.025) without significantly affecting binding affinity $\left(K_{\mathrm{d}}=1.97 \pm 0.2 \mathrm{nM}\right.$; Figure $\left.1 \mathrm{c}\right)$, suggesting an increase in the number of available binding sites for $\left[{ }^{3} \mathrm{H}\right] \mathrm{CP} 55,940$.

\section{ZCZ011 Enhanced CB $_{1}$ Receptor Agonist Signalling}

$\left[{ }^{35}\right.$ S]GTP $\gamma S$ binding. AEA stimulated $\left[{ }^{35} \mathrm{~S}\right] \mathrm{GTP} \gamma \mathrm{S}$ binding in mouse brain membranes with a $\mathrm{pEC}_{50}$ value of $6.5 \pm 0.2$ 
and $E_{\max }$ (efficacy) of $46.5 \%$ (95\% CLs, 40-54; Figure 1d). Addition of $100 \mathrm{nM}$ ZCZ011, significantly enhanced AEA-stimulated $\left[{ }^{35} \mathrm{~S}\right] \mathrm{GTP} \gamma \mathrm{S}$ binding $\left(E_{\max }\right.$ of $115.2 \%(95 \%$ CLs, 104-127)), but there was no significant change in the $\mathrm{pEC}_{50}$ value (potency). A concentration of $10 \mathrm{nM}$ ZCZ011 enhanced AEA-stimulated $\left[{ }^{35} \mathrm{~S}\right] \mathrm{GTP} \gamma \mathrm{S}$ binding with an $E_{\max }$ of $65.4 \%$ (95\% CLs, 51-80); however, this effect was not statistically significant. ZCZ011 alone caused no stimulation of $\left[{ }^{35} \mathrm{~S}\right] \mathrm{GTP} \gamma \mathrm{S}$ binding.

Similarly, CP55,940 stimulated $\left[{ }^{35} \mathrm{~S}\right] \mathrm{GTP} \gamma \mathrm{S}$ binding in mouse brain membranes with a $\mathrm{pEC}_{50}$ value of $8.34 \pm 0.25$ and $E_{\max }$ of $61 \%$ (95\% CLs, 50-72; Supplementary Figure 1a). Addition of $1 \mu \mathrm{M} Z \mathrm{ZCZ} 011$, significantly enhanced AEAstimulated $\left[{ }^{35} \mathrm{~S}\right] \mathrm{GTP} \gamma \mathrm{S}$ binding ( $E_{\max }$ of $100 \%$ (95\% CLs, $82-112)$ ), but there was no significant change in the $\mathrm{pEC}_{50}$ value $(8.80 \pm 0.26)$

\section{PathHunter hCB1 $\beta$-Arrestin Recruitment Assay}

In the PathHunter $\beta$-arrestin assay in $\mathrm{hCB}_{1}$ cells, $\mathrm{AEA}$ stimulated $\beta$-arrestin recruitment with a $\mathrm{pEC}_{50}$ of $6.1 \pm 0.10$ and an $E_{\max }$ of $100 \%$ (95\% CLs, 87-113; Figure 1e). ZCZ011 caused a concentration-dependent enhancement of AEAstimulated $\beta$-arrestin recruitment at $10 \mathrm{nM}, 100 \mathrm{nM}$, and $1 \mu \mathrm{M}$ with $E_{\max }$ values of $99 \%$ (95\% CLs, 90-107) and 157\% (95\% CLs, 138-175) and 195\% (95\% CLs, 185-205), respectively. There was no significant change to the $\mathrm{pEC}_{50}$ value of $6.78 \pm 0.11$ and $7.02 \pm 0.12$ in the presence of $10 \mathrm{nM}$ and $100 \mathrm{nM}$ ZCZ011, respectively. At $1 \mathrm{nM}$ AEA, the maximum stimulation observed was $0.0 \%$ ( $95 \%$ CLs, -6.6 to 6.6 ); however, the addition of $10 \mathrm{nM}, 100 \mathrm{nM}$ and $1 \mu \mathrm{M}$ ZCZ011 significantly increased stimulation to $18.1 \%$ (95\% CLs, 10.8-25.4), $65.1 \%$ (95\% CLs, 47-83), and 161.6\% (95\% CLs, 148-175), respectively. These findings indicate positive cooperativity between the endogenous cannabinoid and ZCZ011. When tested alone, ZCZ011 produced an increase in $\beta$-arrestin recruitment that was $35.9 \%$ (95\% CLs, 33-39) of maximal stimulation.

\section{AlphaScreen Surefire ERK 1/2 Phosphorylation Assay}

Using an AlphaScreen surefire ERK 1/2 phosphorylation assay kit, we measured the effect of ZCZ011 on activation of ERK 1/2 phosphorylation by $\mathrm{CB}_{1}$ agonist, $\mathrm{AEA}$ in $\mathrm{hCB}_{1} \mathrm{R}$ cells (Figure 1f). AEA induced ERK $1 / 2$ phosphorylation with an $E_{\max }$ of $98.2 \%$ (95\% CLs, $\left.79-118\right)$ and $\mathrm{pEC}_{50}$ of $6.5 \pm 0.3$. Neither $10 \mathrm{nM}$ nor $100 \mathrm{nM}$ ZCZ011 significantly affect AEA $E_{\max }$ (efficacy), but $\mathrm{pEC}_{50}$ value (potency) was significantly increased to $8.3 \pm 0.3$ and $8.4 \pm 0.5$, respectively (one-way ANOVA, Dunnett's multiple comparison test, $P<0.05)$. With the exception of the highest concentration $(1 \mu \mathrm{M}), \mathrm{ZCZ} 011$ alone did not induce ERK 1/2 phosphorylation.

CP55,940 induced ERK 1/2 phosphorylation with an $E_{\max }$ of $101 \%$ (95\% CLs, 86-116) and pEC $_{50}$ of $7.85 \pm 0.25$ (Supplementary Figure 1b). $1 \mu \mathrm{M}$ ZCZ011 did not affect the $E_{\max }$ (efficacy) of CP55,940 ( $E_{\max }$ of $119 \%$ (95\% CLs, 107-132)) but $\mathrm{pEC}_{50}$ value (potency) was significantly increased to $8.95 \pm 0.3$ (oneway ANOVA, Dunnett's multiple comparison test, $P<0.05$ ).

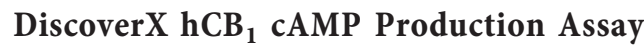

Using a DiscoverX cAMP production assay, we measured the effect of ZCZ011 on activation of ERK 1/2 phosphorylation by $\mathrm{CB}_{1}$ agonist, $\mathrm{AEA}$ in $\mathrm{hCB}_{1}$ cells (Figure 1g). AEA inhibited forskolin-stimulated cAMP production with an $E_{\max }$ of $59 \%$ (95\% CLs, 35-83) and $\mathrm{pEC}_{50}$ of $6.97 \pm 0.35$. Alone, ZCZ011 acted as an agonist; inhibiting forskolinstimulated cAMP production with an $E_{\max }$ of $84 \%$ (95\% CLs, 46-122) and $\mathrm{pEC}_{50}$ of $5.68 \pm 0.33 .100 \mathrm{nM}$ ZCZ011 did not significantly affect AEA. There was evidence positive cooperativity at a concentration of $1 \mu \mathrm{M}$ ZCZ011.

CP55,940 inhibited forskolin-stimulated cAMP production with an $E_{\max }$ of $83 \%$ (95\% CLs, 75-92) and $\mathrm{pEC}_{50}$ of 8.27 \pm 0.13 . $100 \mathrm{nM} \mathrm{ZCZ011} \mathrm{did} \mathrm{not} \mathrm{significantly} \mathrm{affect} \mathrm{AEA.}$ $1 \mu \mathrm{M}$ ZCZ011 did not significantly affect the Emax or pEC50 of CP55,940 (Supplementary Figure 1c).

\section{ZCZ011 Does not Produce Psychoactive Effects in Mice}

ZCZ011 $(40 \mathrm{mg} / \mathrm{kg})$ was detected in whole brain, $6.5 \pm 0.6$ (mean \pm SEM) ng/wet (g), as determined by HPLC/MS/MS (Poklis et al, 2015). Given alone, $40 \mathrm{mg} / \mathrm{kg}$ ZCZ011 did not produce catalepsy ( $0 \mathrm{~s}$ immobility), hypothermia $(P=0.4$; Supplementary Figure 2a), antinociception in tail withdrawal $(P=0.9$; Supplementary Figure $2 \mathrm{~b})$ or hot-plate tests $(P=0.8$; Supplementary Figure $2 c)$, or locomotor depression $(P=0.9$; Supplementary Figure 2d). ZCZ011 did not substitute for either CP55,940 (Supplementary Figure 2e) or AEA (Supplementary Figure 3a) in the drug discrimination assay and did not affect respective response rates for either training drug $(P=0.9$; Supplementary Figure $2 \mathrm{f}$ and $P=0.9, P=0.1$; Supplementary Figure 3b). Also, ZCZ011 (40 mg/kg) did not elicit a conditioned place preference or aversion compared with vehicle $(P=0.2$; Supplementary Figure 4$)$.

\section{ZCZ011 Potentiates the Pharmacological Effects of AEA and CP55,940 in Mice}

In contrast to its ineffectiveness to elicit cannabimimetic effects when administered alone, ZCZ011 significantly augmented the antinociceptive $(\mathrm{F}(1,14)=8.0, P<0.01)$, cataleptic $\quad(\mathrm{F}(2,28)=3.84, \quad P<0.05), \quad$ and hypothermic $(\mathrm{F}(1,14)=5.5 ; \quad P<0.05)$ effects of $\mathrm{CP} 55,940$ (Figure 2a-c). It also enhanced AEA-induced hypothermia $(\mathrm{F}(4,64)=2.93 ; P<0.05$; Figure $2 \mathrm{~d})$, but did not affect the antinociceptive $(P=0.8$; Figure $2 \mathrm{e})$ or cataleptic $(P=1$; Figure $2 \mathrm{f})$ effects of AEA in FAAH $(-/-)$ mice. Also, this compound did not alter the antinociceptive effects of $1 \mathrm{mg} /$ kg nicotine (Supplementary Figure 5).

In the drug discrimination assay, ZCZ011 (40 mg/kg) significantly increased the potency of the discriminative stimulus effects of AEA in FAAH $(-/-)$ mice (F $(4,48)=10.47, \quad P<0.001 ;$ Supplementary Figure 3a). The respective $\mathrm{ED}_{50}(95 \% \mathrm{CI})$ values of $\mathrm{AEA}$ in the vehiclepretreated mice and ZCZ011-pretreated mice were 4.0 (2.7$5.9) \mathrm{mg} / \mathrm{kg}$ and $1.4(1.2-1.7) \mathrm{mg} / \mathrm{kg}$. ZCZ011 increased AEA potency 2.2 -fold compared with the vehicle-pretreated mice. ZCZ011 (20 mg/kg) also significantly enhanced the discriminative cue of AEA. Although ZCZ011 (40 mg/kg) given alone or in combination with AEA did not affect response rates of FAAH $(-/-)$ mice in the drug discrimination paradigm (Supplementary Figure $3 \mathrm{~b}$ ), it potentiated the depressive effects of AEA $(5.6 \mathrm{mg} / \mathrm{kg}$ ) on operant responding for food in a separate group of mice $(\mathrm{F}(1,4)=6.88, P<0.05$; Supplementary Figure 6). 
a

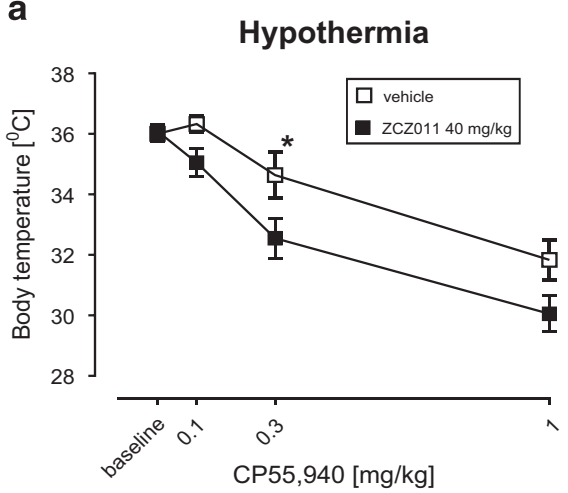

d

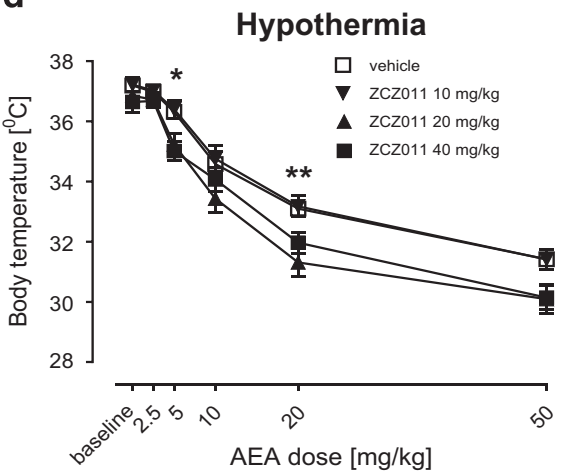

b

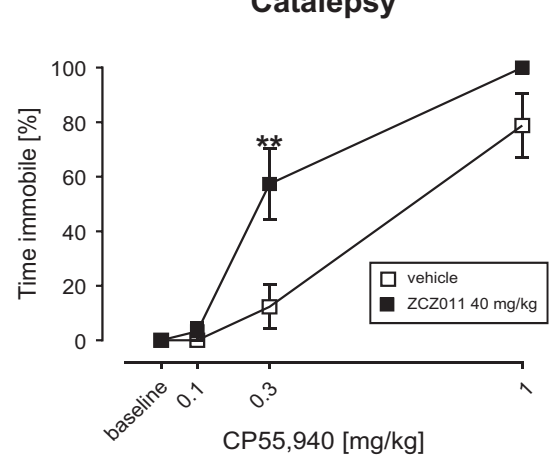

e

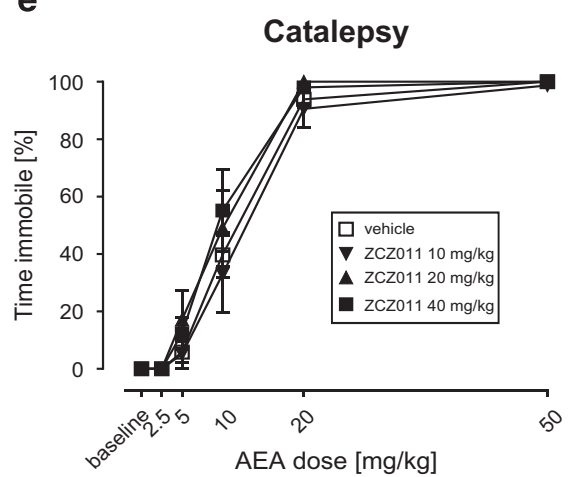

C

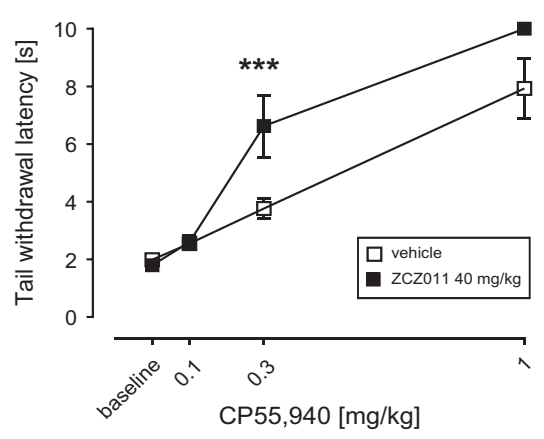

f

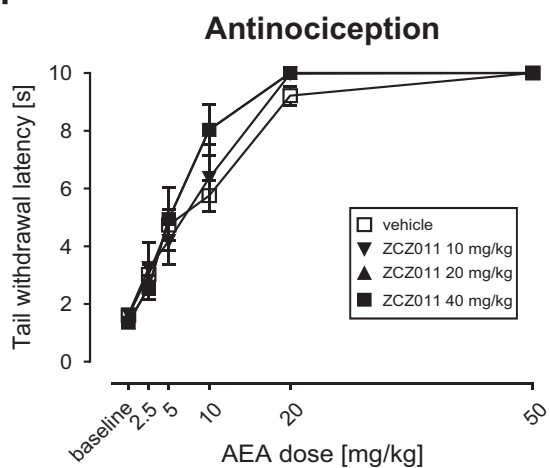

Figure 2 ZCZOII (40 mg/kg) potentiated the pharmacological effects of orthosteric CB, receptor agonists CP55,940 and AEA. ZCZ0II significantly enhanced CP55,940-induced hypothermia (a), catalepsy (b), and antinociception (c) in C57BL/6) mice and AEA-induced hypothermia (d), but not AEAinduced catalepsy (e) or antinociception ( $\mathrm{f})$, in FAAH $(-/-)$ mice. Data presented as mean \pm SEM; $n=8-9$ mice per group; *P<0.05, ** $P<0.01$, **** $P<0.001$ vs vehicle.

\section{ZCZ011 Reverses Nociceptive Behavior in Neuropathic and Inflammatory Pain Models}

ZCZ011 enhanced the pharmacological effects of AEA and CP55,940 in in vitro and in behavioral assays, but did not produce common cannabimimetic effects on its own. Accordingly, we next investigated whether it would reverse nociceptive behavior in well-established models of neuropathic and inflammatory pain. As has been previously shown (Kinsey et al, 2010), the FAAH inhibitor, PF-3845, reversed mechanical (Figure 3a) and cold allodynia (Figure $3 \mathrm{~b}$ ) in the CCI model of neuropathic pain. These findings are consistent with the idea that AEA, which is rapidly hydrolyzed by FAAH, has an autoprotective role in this model. Similarly, ZCZ011 completely reversed mechanical $(\mathrm{F}(3,42)=7.6$, $P<0.001$; Figure 3a) and cold allodynia $(\mathrm{F}(3,42)=3.6$, $P<0.05$; Figure $3 \mathrm{~b}$ ) in the CCI model of neuropathic pain. Unlike endocannabinoid catabolic enzyme inhibitors; however, ZCZ011 $(40 \mathrm{mg} / \mathrm{kg})$ did not affect whole brain levels of 2-AG $(P=0.3)$, AEA $(P=0.3)$, palmitoylethanolamide $(P=0.3)$, or oleoylethanolamide $(P=1)$ in $\mathrm{C} 57 \mathrm{BL} / 6 \mathrm{~J}$ mice (Supplementary Figure 7).

These anti-allodynic actions of ZCZ011 were prevented by the $\mathrm{CB}_{1}$ receptor antagonist, rimonabant $(3 \mathrm{mg} / \mathrm{kg})$, but not by the $\mathrm{CB}_{2}$ receptor antagonist, SR144528 $(3 \mathrm{mg} / \mathrm{kg}$; $\mathrm{F}(3,28)=8.9, P<0.001$; Figure $3 \mathrm{c}$ and $\mathrm{d})$, indicating a $\mathrm{CB}_{1}$ receptor-mediated mechanism of action.

ZCZ011 $(40 \mathrm{mg} / \mathrm{kg})$ blocked mechanical allodynia $(\mathrm{F}(4,56)=$ 6.0, $P<0.001)$ and cold allodynia $(F(4,56)=4.44, P<0.01$;
Figure $4 \mathrm{a}$ and $\mathrm{b}$ ) for durations of 12 and $4 \mathrm{~h}$, respectively. The anti-allodynic effects of ZCZ011 (40 mg/kg) to mechanical $(\mathrm{F}(2,21)=8.9, \quad P<0.01 ;$ Figure $4 \mathrm{c})$ and cold $(\mathrm{F}(2,21)=7.0$, $P<0.01$; Figure 4d) stimuli were retained following 6 days of daily injections and did not differ from the antinociceptive effects produced by acute ZCZ011. Thus, the antinociceptive effects of ZCZ011 were resistant to tolerance.

Likewise, ZCZ011 (40 mg/kg) partially reversed carrageenaninduced mechanical allodynia $(\mathrm{F}(2,21)=22.3, \quad P<0.001$; Figure 5a), which required $\mathrm{CB}_{1}$ receptors, but not $\mathrm{CB}_{2}$ receptors $(\mathrm{F}(1,16)=14.7, P<0.01$; Figure $5 \mathrm{~b})$. Consistent with its lack of $\mathrm{CB}_{2}$ receptor action, ZCZ011 did not reduce carrageenaninduced paw edema (Figure $5 c$ and d; $P=0.8$ ).

\section{DISCUSSION}

Here we report the development and pharmacological characterization of the novel synthetic $\mathrm{CB}_{1}$ receptor PAM, ZCZ011. This compound increased equilibrium binding of the potent $\mathrm{CB}_{1}$ receptor orthosteric agonist, $\mathrm{CP} 55,940$. In addition, ZCZ011 enhanced the efficacy of AEA in stimulating $\left[{ }^{35} \mathrm{~S}\right] \mathrm{GTP} \gamma \mathrm{S}$ binding in whole brain as well as $\beta$-arrestin recruitment and the potency of AEA in ERK phosphorylation assays in $\mathrm{hCB}_{1}$ cells. In mice, ZCZ011 potentiated CP55,940-induced catalepsy, hypothermia, and antinociception. It also increased the potency of AEA in several in vivo assays employing FAAH $(-/-)$ mice, including the discriminative stimulus effects of AEA, AEA-induced 
a
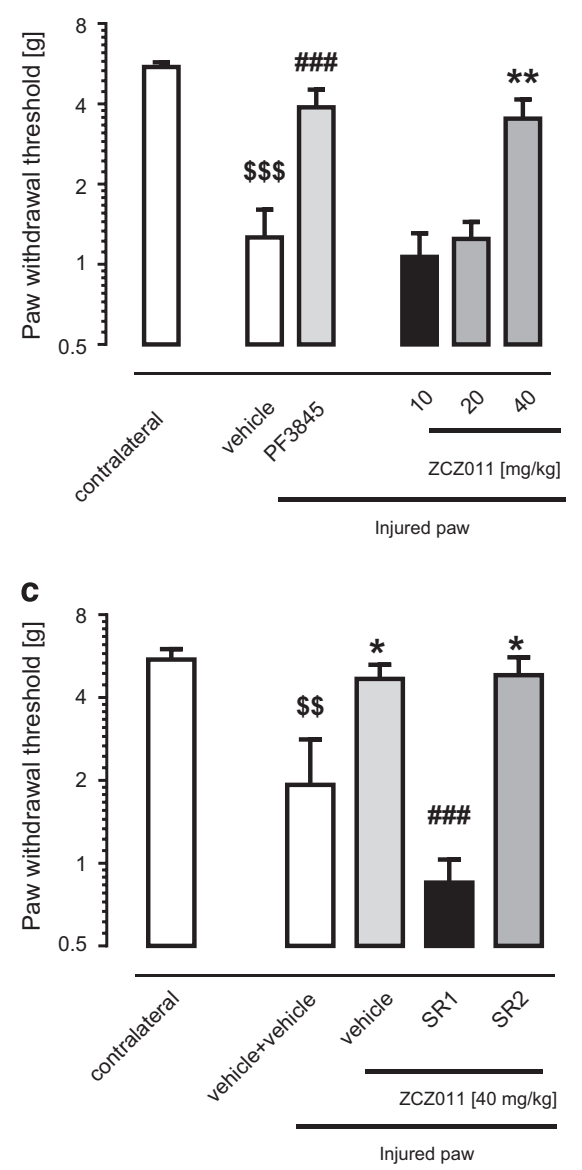

b

\section{Cold allodynia}

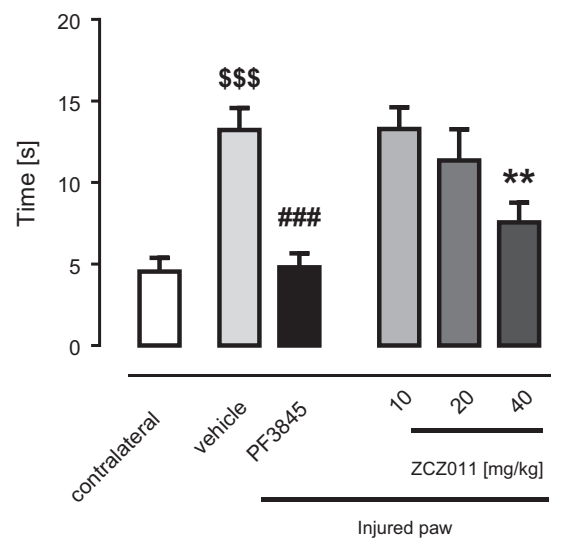

d

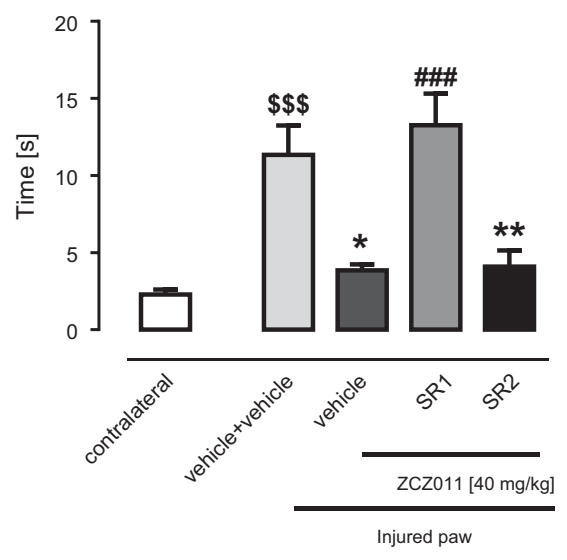

Figure 3 ZCZOII significantly reduced mechanical (a) and cold (b) allodynia induced by chronic constriction nerve injury (CCI). The anti-allodynic effects of ZCZOI I (40 mg/kg, i.p.) were blocked by the $\mathrm{CB}_{1}$ receptor antagonist rimonabant (SRI4I7I6A, SRI; $3 \mathrm{mg} / \mathrm{kg}$; $\mathrm{C}$ ), but not by the $\mathrm{CB}_{2}$ receptor antagonist SRI 44528 (SR2; 3 mg/kg; d). The FAAH inhibitor, PF-3845 ( 10 mg/ $/ \mathrm{kg}$, i.p.) was included for comparison. Results presented as mean \pm SEM $(n=9-12$ mice per group); ${ }^{*} P<0.05$, ${ }^{*} * P<0.01$, ${ }^{\# \#} P<0.001$ vs vehicle; ${ }^{\$} P<0.01$, ${ }^{\$ \$} P P<0.001$ vs contralateral paw.

depression of operant responding for food, and AEAinduced hypothermia. Most strikingly, when administered alone, ZCZ011 completely reversed allodynia in the CCI model of neuropathic pain and partially reversed carrageenan-induced allodynia, but did not elicit any apparent cannabimimetic side effects. Its actions in the $\mathrm{CCI}$ model required $\mathrm{CB}_{1}$ receptors, were of long duration (ie, up to $12 \mathrm{~h}$ ), and did not undergo tolerance after 6 days of treatment. Accordingly, we hypothesize that ZCZ011 blocked neuropathic pain, without eliciting general cannabimimetic activity, by augmenting the actions of endocannabinoids at $\mathrm{CB}_{1}$ receptors in pathways mediating nociceptive responses following sciatic nerve injury. Likewise, ZCZ011 reduced carrageenan-induced allodynia through a $\mathrm{CB}_{1}$ receptor mechanism of action, and did not reduce the edematous effects of carrageenan. Thus, this study provides compelling parallel in vitro and in vivo evidence that ZCZ011 acts as a $\mathrm{CB}_{1}$ receptor PAM. Accordingly, ZCZ011 represents a valuable pharmacological tool for mechanistic studies as well as for exploring potential therapeutic applications of $\mathrm{CB}_{1}$ receptor allosteric target(s).

Our in vivo observations showing that ZCZ011 potentiated the pharmacological effects of either CP55,940 or AEA in behavioral assays confirm in vitro observations showing that ZCZ011 acts as a $\mathrm{CB}_{1} \mathrm{PAM}$ and enhances the signalling of the bound agonist. ZCZ011 $(1 \mu \mathrm{M})$ caused an increase in the $B_{\max }$ of $\left[{ }^{3} \mathrm{H}\right] \mathrm{CP} 55,940$ and $\left[{ }^{3} \mathrm{H}\right]$ WIN55212, which implies an increase in the number of available receptors for CP55,940 to bind. Intriguingly, ZCZ011 elicited an apparent displacement of the $\mathrm{CB}_{1}$ receptor inverse agonist, SR141716A. With the exception of cAMP activity, ZCZ011 increased $\mathrm{CB}_{1}$ orthosteric agonist potency and/or efficacy in all the functional assays performed. Specifically, ZCZ011 potentiated AEA and CP55,940 signaling efficacy in the $\left[{ }^{35} \mathrm{~S}\right] \mathrm{GTP} \gamma \mathrm{S}$ binding in mouse brain membranes and increased the potency of AEA and $\mathrm{CP} 55,940$ in the ERK phosphorylation assay in $\mathrm{hCB}_{1}$ cells, and enhanced the potency of AEA-mediated $\beta$-arrestin recruitment. This evidence strongly suggests that ZCZ011 acts as a $\mathrm{CB}_{1}$ PAM both in vitro and in vivo. In the cAMP assay, ZCZ011 acted as an agonist alone, but did not affect the potency or efficacy of AEA or CP55,940 at a concentration of $1 \mu \mathrm{M}$.

A highly novel finding in the present study was that ZCZ011 produced anti-allodynic effects in CCI model of neuropathic pain. Previous studies have also demonstrated that the anti-allodynic effects of FAAH inhibitors (Kinsey 
a

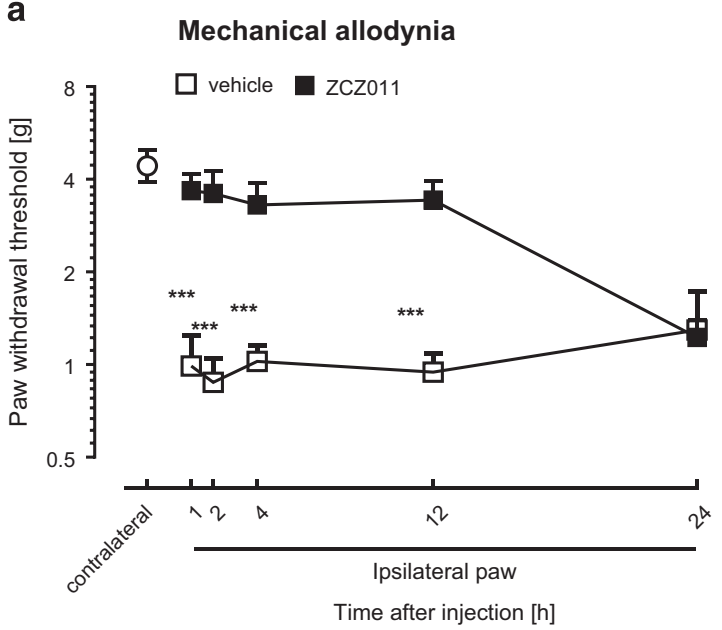

C

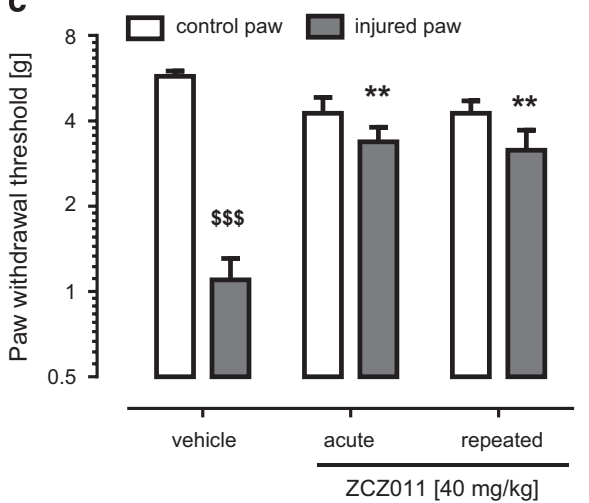

b

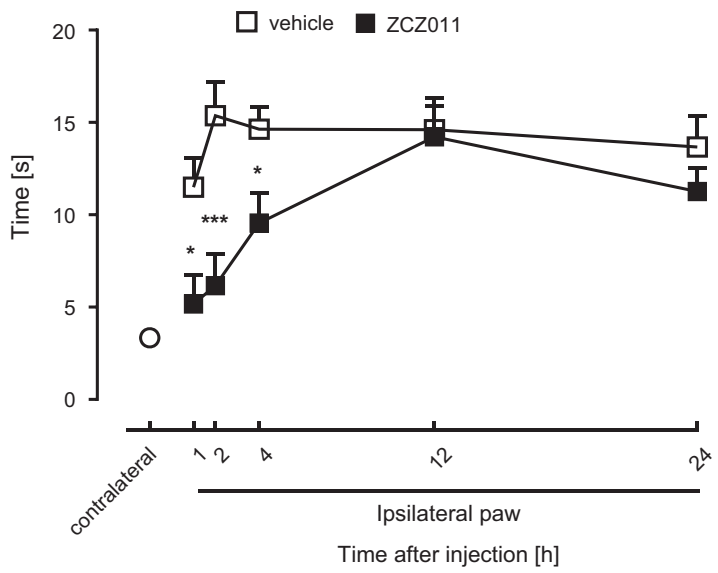

d

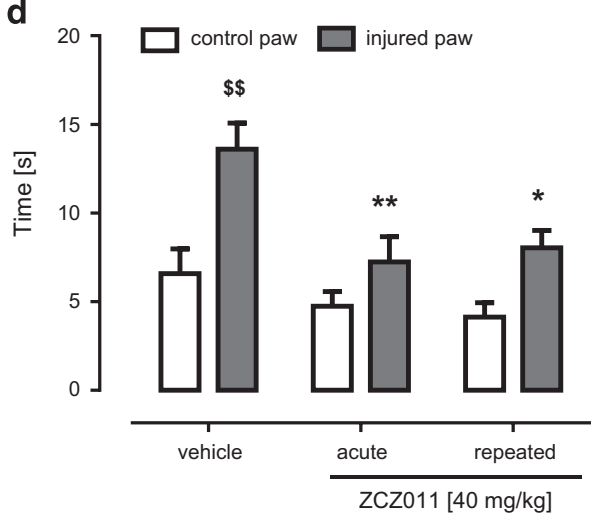

Figure 4 The anti-allodynic effects of ZCZOII (40 mg/kg) are of long duration and do not undergo tolerance after 6 days of daily injections in the CCl model of neuropathic pain. ZCZO I s significantly reversed mechanical allodynia for up to $12 \mathrm{~h}$ (a) and cold allodynia for up to $4 \mathrm{~h}$ (b). The anti-allodynic effects of ZCZOII are retained following 6 days of repeated administration in response to tactile (c) and cold (d) stimulation. Values represent mean \pm SEM, $n=8$ mice per group, ${ }^{*} P<0.05$, $* * P<0.01$, ${ }^{* * *} * P<0.001$ vs vehicle, ${ }^{\$ \$} P<0.0$ I, ${ }^{\$ \$} P<0.00$ I vs contralateral paw.

et al, 2009, 2010), as well as MAGL inhibitors JZL184 and KML29 (Kinsey et al, 2009, 2010; Ignatowska-Jankowska et al, 2014) elicited anti-allodynic effects in the CCI assay. Repeated administration of high-dose ZCZ011 retained its antinociceptive effects, which is similar to the finding that the antinociceptive effects produced by FAAH inhibition also do not undergo tolerance (Schlosburg et al, 2010). Although repeated high doses of MAGL inhibitors leads to antinociceptive tolerance associated with $\mathrm{CB}_{1}$ receptor downregulation and desensitization (Schlosburg et al, 2010; Ignatowska-Jankowska et al, 2014), $\mathrm{CB}_{1}$ receptor function is retained following repeated low doses of the MAGL inhibitor JZL184 (Sciolino et al, 2011; Kinsey et al, 2013). The most notable difference between ZCZ011 and endocannabinoid catabolic enzyme inhibitors is that ZCZ011 did not alter the concentration of endocannabinoids or other $\mathrm{N}$-acylethanoloamines in the brain (Supplementary Figure 7). In contrast, FAAH and MAGL inhibitors produce increased brain levels of AEA (Kathuria et al, 2003) and 2AG (Long et al, 2009a), respectively. The anti-allodynic effects of ZCZ011 in the CCI assay were $\mathrm{CB}_{1}$, but not $\mathrm{CB}_{2}$, receptor dependent. In contrast, $\mathrm{FAAH}$ inhibitors require both $\mathrm{CB}_{1}$ and $\mathrm{CB}_{2}$ receptors to reverse CCI-induced allodynia (Kinsey et al, 2009, 2010). In addition, FAAH (Holt et al, 2005) and MAGL (Ghosh et al, 2013) inhibitors produce anti-edematous actions in the carrageenan assay, which in each case was completely blocked by a $\mathrm{CB}_{2}$ receptor antagonist and not a $\mathrm{CB}_{1}$ receptor antagonist. Thus, a $\mathrm{CB}_{1}$ $\mathrm{PAM}$ would not be expected to reduce carrageenan-induced paw edema, as the case in the present study. Collectively, these findings are consistent with the idea that the antiallodynic effects of ZCZ011 in the CCI and carrageenan assays are mediated through its actions as a $\mathrm{CB}_{1} \mathrm{PAM}$ by enhancing the activity of endocannabinoids at $\mathrm{CB}_{1}$ receptors.

An important observation from a drug development perspective is that ZCZ011 did not produce cannabimimetic side effects (ie, catalepsy, hypothermia, thermal antinociception, or hypomotility) and did not substitute for AEA or CP55,940 in the drug discrimination paradigm. However, ZCZ011 enhanced many pharmacological effects produced by these orthosteric agonists, consistent with in vitro data showing that it acts as a $\mathrm{CB}_{1}$ receptor PAM. Although it is interesting that ZCZ011 augmented more of the measured actions produced by CP55,940 than those elicited by AEA, it is known that allosteric modulators affect orthosteric agonists in a ligand-dependent manner. The failure of ZCZ011 to affect nicotine-induced antinociception in the tail withdrawal and hot-plate tests (Supplementary Figure 5) shows that its effects are selective to cannabinergic ligands. 
a

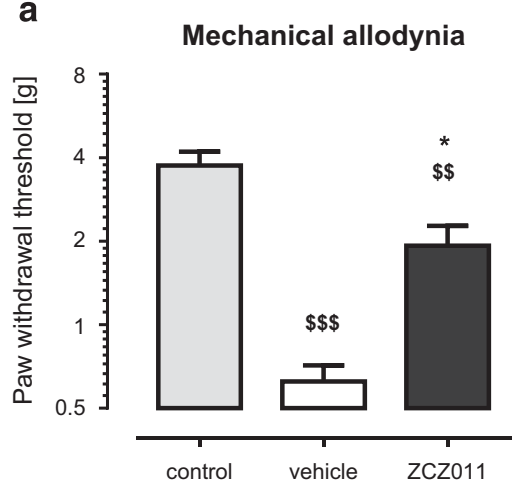

C

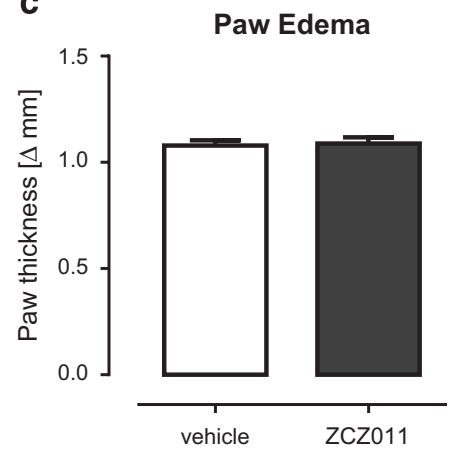

b

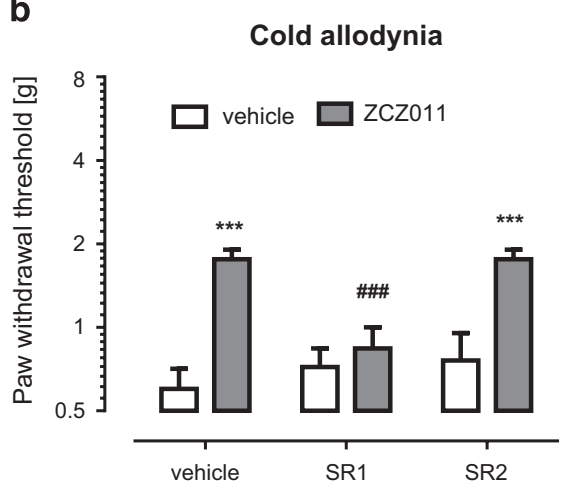

d

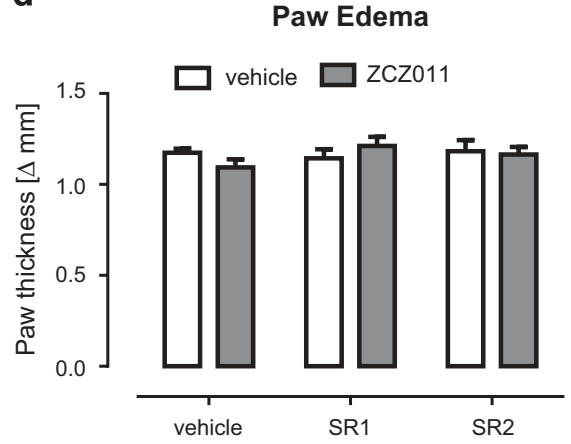

Figure $5 \mathrm{ZCZOII}$ partially reversed mechanical allodynia in the carrageenan model of inflammatory pain. The $\mathrm{CB}_{\text {| }}$ receptor antagonist rimonabant (SRI4I7I6A, SRI; 3 mg/kg; (a), but not the $\mathrm{CB}_{2}$ receptor antagonist SRI44528 (SR2; $3 \mathrm{mg} / \mathrm{kg}$; b) blocked the anti-allodynic effects of ZCZ0II. Results presented as mean \pm SEM ( $n=9-12$ mice per group). ZCZOII (40 mg/ $/ \mathrm{kg}$, i.p.) did not attenuate carrageenan-induced paw edema (c and d). Values represent

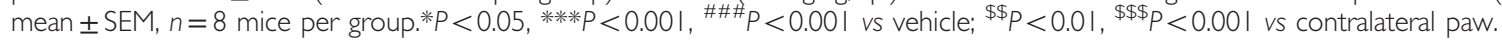

Pamplona et al. (2012) presented the first in vivo and in vitro evidence demonstrating that the endogenous antiinflammatory mediator, lipoxin $\mathrm{A} 4$, acts as a $\mathrm{CB}_{1}$ PAM. This naturally occurring lipid enhanced both $\mathrm{CB}_{1}$ receptor binding of AEA and AEA-induced cAMP inhibition. Moreover, when given via the i.c.v. route of administration, lipoxin A4 produced cannabimimetic effects (ie, catalepsy, hypothermia, hypomotility, and antinociceptive effects in the hot-plate test). Notably, systemic administration of an inhibitor of 5-lipoxygenase, the primary biosynthetic enzyme of lipoxin A4, attenuated the cataleptic effects of i.c.V administered AEA, suggesting that this endogenous lipid contributes to the behavioral actions of $\mathrm{CB}_{1}$ orthosteric agonists. In addition, i.c.v. administration of lipoxin A4 protected mice from impaired spatial memory performance in the Morris water maze task elicited by i.c.v. injection of $\beta$-amyloid (1-40) protein. This protective effect was blocked by rimonabant, indicating a $\mathrm{CB}_{1}$ receptor-mediated mechanism of action. The data presented here with ZCZ011, together with those previously published with lipoxin A4 (Pamplona et al, 2012), provide compelling proof of principle that $\mathrm{CB}_{1}$ PAMs offer promise as therapeutic strategies for neurodegenerative diseases and pain states related to nerve injury. The identification of the putative binding site(s) of ZCZ011 and lipoxin $A 4$ at the $\mathrm{CB}_{1}$ receptor will be a crucial step for future development of allosteric modulators of the $\mathrm{CB}_{1}$ receptor as well as better understanding of the physiological function of $\mathrm{CB}_{1}$ allosteric modulation for the development of novel pharmacotherapies based on this mechanism. Nonetheless, the present study demonstrates that the synthetic $\mathrm{CB}_{1}$ PAM, ZCZ011, produces $\mathrm{CB}_{1}$-mediated anti-allodynic effects in murine models of neuropathic and inflammatory pain without the development of tolerance or the occurrence of cannabimimetic side effects.

\section{FUNDING AND DISCLOSURE}

RAR, IRG, and MZ are inventors on patent applications filed by the Universities of Toronto and Aberdeen, which disclose pharmaceutical agents targeting molecular pathways described in the present article. RAR, IRG and MZ have an equity share in Signal Pharma Ltd, a University spin-out company developing CB1-positive allosteric modulators. Research was supported by NIH grants DA-009789, DA-026449, DA-003672 and CIHR Proof of Principal Phase 1 grant 288645. The remaining authors declare no competing financial interests.

\section{REFERENCES}

Ahn KH, Mahmoud MM, Samala S, Lu D, Kendall DA (2013). Profiling two indole-2-carboxamides for allosteric modulation of the CB1 receptor. J Neurochem 124: 584-589.

Baillie GL, Horswill JG, Anavi-Goffer S, Reggio PH, Bolognini D, Abood ME et al (2013). CB(1) receptor allosteric modulators display both agonist and signaling pathway specificity. Mol Pharmacol 83: 322-338. 
Cooper ZD, Haney M (2009). Actions of delta-9-tetrahydrocannabinol in cannabis: relation to use, abuse, dependence. Int Rev Psychiatry 21: 104-112.

Cravatt BF, Demarest K, Patricelli MP, Bracey MH, Giang DK, Martin BR et al (2001). Supersensitivity to anandamide and enhanced endogenous cannabinoid signaling in mice lacking fatty acid amide hydrolase. Proc Natl Acad Sci USA 98: 9371-9376.

Devane WA, Hanus L, Breuer A, Pertwee RG, Stevenson LA, Griffin $G$ et al (1992). Isolation and structure of a brain constituent that binds to the cannabinoid receptor. Science 258: 1946-1949.

Di Marzo V, De Petrocellis L, Bisogno T, Meick D (1999). Metaboloism of anadamide and 2-arachidonoylglycerol: an historical overview and some recent developments. Lipids 34: S319-S325.

Di Marzo V, Goparaju SK, Wang L, Liu J, Batkai S, Jarai Z et al (2001). Leptin-regulated endocannabinoids are involved in maintaining food intake. Nature 410: 822-825.

Ding Y, Qiu Y, Jing L, Thorn DA, Zhang Y, Li JX (2014). Behavioral effects of the cannabinoid CB1 receptor allosteric modulator ORG27569 in rats. Pharmacol Res Perspect 2: e00069.

Falenski KW1, Thorpe AJ, Schlosburg JE, Cravatt BF, Abdullah RA, Smith TH et al (2010). FAAH-/- mice display differential tolerance, dependence, and cannabinoid receptor adaptation after delta 9-tetrahydrocannabinol and anandamide administration. Neuropsychopharmacology 35: 1775-1787.

Fagan SG, Campbell VA (2014). The influence of cannabinoids on generic traits of neurodegeneration. Br J Pharmacol 171: 1347-1360.

Gamage TF, Ignatowska-Jankowska BM, Wiley JL, Abdelrahman M, Trembleau L, Greig IR et al (2014). In-vivo pharmacological evaluation of the CB1-receptor allosteric modulator Org-27569. Behav Pharmacol 25: 182-185.

Gaoni Y, Mechoulam R (1964). Isolation, structure, and partial synthesis of an active constituent of hashish. J Amer Chem Soc 86: 1646-1647.

Ghosh S, Wise LE, Chen Y, Gujjar R, Mahadevan A, Cravatt BF et al (2013). The monoacylglycerol lipase inhibitor JZL184 suppresses inflammatory pain in the mouse carrageenan model. Life Sci 92: 498-505.

Guindon J, Hohmann AG (2009). The endocannabinoid system and pain. CNS Neurol Disorders Drug Targets 8: 403-421.

Hampson RE, Deadwyler SA (2000). Cannabinoids reveal the necessity of hippocampal neural encoding for short-term memory in rats. J Neurosci 20: 8932-8942.

Holt S, Comelli F, Costa B, Fowler CJ (2005). Inhibitors of fatty acid amide hydrolase reduce carrageenan-induced hind paw inflammation in pentobarbital-treated mice: comparison with indomethacin and possible involvement of cannabinoid receptors. $\mathrm{Br} J$ Pharmacol 146: 467-476.

Horswill JG, Bali U, Shaaban S, Keily JF, Jeevaratnam P, Babbs AJ et al (2007). PSNCBAM-1, a novel allosteric antagonist at cannabinoid CB1 receptors with hypophagic effects in rats. $\mathrm{Br} \mathrm{J}$ Pharmacol 152: 805-814.

Hutcheson DM, Tzavara ET, Smadja C, Valjent E, Roques BP, Hanoune J et al (1998). Behavioural and biochemical evidence for signs of abstinence in mice chronically treated with delta-9tetrahydrocannabinol. Br J Pharmacol 125: 1567-1577.

Ignatowska-Jankowska BM, Ghosh S, Crowe MS, Kinsey SG, Niphakis MJ, Abdullah RA et al (2014). In vivo characterization of the highly selective monoacylglycerol lipase inhibitor KML29: antinociceptive activity without cannabimimetic side effects. $\mathrm{Br} \mathrm{J}$ Pharmacol 171: 1392-1407.

Jarbe TU, Swedberg MD, Mechoulam R (1981). A repeated test procedure to assess onset and duration of the cue properties of ( - ) delta 9-THC, $(-)$ delta 8-THC-DMH and (+) delta 8-THC. Psychopharmacology 75: 152-157.

Jing L, Qiu Y, Zhang Y, Li JX (2014). Effects of the cannabinoid $\mathrm{CB}_{1}$ receptor allosteric modulator ORG 27569 on reinstatement of cocaine- and methamphetamine-seeking behavior in rats. Drug Alcohol Depend. 143: 251-256.

Justinova Z, Tanda G, Redhi GH, Goldberg SR (2003). Selfadministration of delta9-tetrahydrocannabinol (THC) by drug naive squirrel monkeys. Psychopharmacology 169: 135-140.

Kathuria S, Gaetani S, Fegley D, Valino F, Duranti A, Tontini A et al (2003). Modulation of anxiety through blockade of anandamide hydrolysis. Nat Med 9: 76-81.

Kenakin T (2004). Principles: receptor theory in pharmacology. Trends Pharmacol Sci 25: 186-192.

Kenakin T (2013). Analytical pharmacology and allosterism: the importance of quantifying drug parameters in drug discovery. Drug Discov Today Technol 10: e229-e235.

Kinsey SG, Long JZ, Cravatt BF, Lichtman AH (2010). Fatty acid amide hydrolase and monoacylglycerol lipase inhibitors produce anti-allodynic effects in mice through distinct cannabinoid receptor mechanisms. J Pain 11: 1420-1428.

Kinsey SG, Long JZ, O'Neal ST, Abdullah RA, Poklis JL, Boger DL et al (2009). Blockade of endocannabinoid-degrading enzymes attenuates neuropathic pain. J Pharmacol Exp Ther 330: 902-910.

Kinsey SG, Wise LE, Ramesh D, Abdullah R, Selley DE, Cravatt BF et al (2013). Repeated low-dose administration of the monoacylglycerol lipase inhibitor JZL184 retains cannabinoid receptor type 1-mediated antinociceptive and gastroprotective effects. J Pharmacol Exp Ther 345: 492-501.

Kota D, Martin BR, Damaj MI (2008). Age-dependent differences in nicotine reward and withdrawal in female mice. Psychopharmacology 198: 201-210.

Lichtman AH, Dimen KR, Martin BR (1995). Systemic or intrahippocampal cannabinoid administration impairs spatial memory in rats. Psychopharmacology 119: 282-290.

Lichtman AH, Hawkins EG, Griffin G, Cravatt BF (2002). Pharmacological activity of fatty acid amides is regulated, but not mediated, by fatty acid amide hydrolase in vivo. J Pharmacol Exp Ther 302: 73-79.

Lichtman AH, Leung D, Shelton C, Saghatelian A, Hardouin C, Boger D et al (2004). Reversible inhibitors of fatty acid amide hydrolase that promote analgesia: evidence for an unprecedented combination of potency and selectivity. J Pharmacol Exp Ther 311: 441-448.

Little PJ, Compton DR, Johnson MR, Melvin LS, Martin BR (1988). Pharmacology and stereoselectivity of structurally novel cannabinoids in mice. J Pharmacol Exp Ther 247: 1046-1051.

Long JZ, Li W, Booker L, Burston JJ, Kinsey SG, Schlosburg JE et al (2009a). Selective blockade of 2-arachidonoylglycerol hydrolysis produces cannabinoid behavioral effects. Nat Chem Biol 5: 37-44.

Long JZ, Nomura DK, Vann RE, Walentiny DM, Booker L, Jin X et al (2009b). Dual blockade of FAAH and MAGL identifies behavioral processes regulated by endocannabinoid crosstalk in vivo. Proc Natl Acad Sci USA 106: 20270-20275.

Mechoulam R, Ben-Shabat S, Hanus L, Ligumsky M, Kaminski NE, Schatz AR et al (1995). Identification of an endogenous 2monoglyceride, present in canine gut, that binds to cannabinoid receptors. Biochem Pharmacol 50: 83-90.

National Research Council (2011). Institutional Animal Care and Use Committees at Virginia Commonwealth University and West Virginia University and were in accordance with the National Institutes of Health Guide for the Care and Use of Laboratory Animals.

Navarro HA, Howard JL, Pollard GT, Carroll FI (2009). Positive allosteric modulation of the human cannabinoid (CB) receptor by RTI-371, a selective inhibitor of the dopamine transporter. $\mathrm{Br} J$ Pharmacol 156: 1178-1184.

Nightingale S (2012). The neuropathic pain market. Nat Rev Drug Discov 11: 101-102.

Pamplona FA, Ferreira J, Menezes de Lima O Jr, Duarte FS, Bento AF, Forner S et al (2012). Anti-inflammatory lipoxin A4 is 
an endogenous allosteric enhancer of $\mathrm{CB} 1$ cannabinoid receptor. Proc Natl Acad Sci USA 109: 21134-21139.

Pertwee RG (2005). The therapeutic potential of drugs that target cannabinoid receptors or modulate the tissue levels or actions of endocannabinoids. AAPS J 7: E625-E654.

Piscitelli F, Ligresti A, La Regina G, Coluccia A, Morera L, Allara M et al (2012). Indole-2-carboxamides as allosteric modulators of the cannabinoid CB(1) receptor. J Med Chem 55: 5627-5631.

Poklis J, Clay D, Ignatowska-Jankowska B, Zanato C, Ross R, Greig I et al (2015). HPLC/MS/MS Determination of ZCZ-011, a Novel Pharmacological Tool for Investigation the Cannabinoid Receptor in Mouse Brain Using Clean Screen FAStTM Column Extraction. J Chromatography B 39: 353-358.

Price MR, Baillie GL, Thomas A, Stevenson LA, Easson M, Goodwin R et al (2005). Allosteric modulation of the cannabinoid CB1 receptor. Mol Pharmacol 68: 1484-1495.

Pryce G, Baker D (2012). Potential control of multiple sclerosis by cannabis and the endocannabinoid system. CNS Neurol Disord Drug Targets 11: 624-641.

Ross RA (2007a). Allosterism and cannabinoid CB(1) receptors: the shape of things to come. Trends Pharmacol Sci 28: 567-572.

Ross RA (2007b). Tuning the endocannabinoid system: allosteric modulators of the CB1 receptor. Br J Pharmacol 152: 565-566.

Russo R, Loverme J, La Rana G, Compton TR, Parrott J, Duranti A et al (2007). The fatty acid amide hydrolase inhibitor URB597 (cyclohexylcarbamic acid 3'-carbamoylbiphenyl-3-yl ester) reduces neuropathic pain after oral administration in mice. J Pharmacol Exp Ther 322: 236-242.

Schlosburg JE, Blankman JL, Long JZ, Nomura DK, Pan B, Kinsey SG et al (2010). Chronic monoacylglycerol lipase blockade causes functional antagonism of the endocannabinoid system. Nat Neurosci 13: 1113-1119.

Sciolino NR, Zhou W, Hohmann AG (2011). Enhancement of endocannabinoid signaling with JZL184, an inhibitor of the 2-arachidonoylglycerol hydrolyzing enzyme monoacylglycerol lipase, produces anxiolytic effects under conditions of high environmental aversiveness in rats. Pharmacol Res 64: 226-234.

Sugiura T, Kondo S, Sukagawa A, Nakane S, Shinoda A, Itoh K et al (1995). 2-Arachidonoylglycerol: a possible endogenous cannabinoid receptor ligand in brain. Biochem Biophys Res Commun 215: 89-97.

Walker JM, Huang SM, Strangman NM, Tsou K, Sanudo-Pena MC (1999). Pain modulation by release of the endogenous cannabinoid anandamide. Proc Natl Acad Sci USA 96: 12198-12203.

Wiley JL, Razdan RK, Martin BR (2006). Evaluation of the role of the arachidonic acid cascade in anandamide's in vivo effects in mice. Life Sci 80: 24-35.

Wise LE, Cannavacciulo R, Cravatt BF, Martin BF, Lichtman AH (2008). Evaluation of fatty acid amides in the carrageenaninduced paw edema model. Neuropharmacology 54: 181-188.

Supplementary Information accompanies the paper on the Neuropsychopharmacology website (http://www.nature.com/npp) 